\title{
Characterization of a Sea Buckthorn Extract and Its Effect on Free and Encapsulated Lactobacillus casei
}

\author{
Oana Lelia Pop ${ }^{1}$, Francisc Vasile Dulf ${ }^{2}$ (D), Lucian Cuibus ${ }^{1}$ (D), Marta Castro-Giráldez ${ }^{3}$, \\ Pedro J. Fito ${ }^{3}$, Dan Cristian Vodnar ${ }^{1}$, Cristina Coman ${ }^{1}{ }^{\mathbb{B}}$, Carmen Socaciu ${ }^{1}$ and \\ Ramona Suharoschi ${ }^{1, *}$ \\ 1 Faculty of Food Science and Technology, University of Agricultural Sciences and Veterinary Medicine, \\ Calea Mănăștur 3-5, 400372 Cluj-Napoca, Romania; oana.pop@usamvcluj.ro (O.L.P.); \\ lucian.cuibus@usamvcluj.ro (L.C.); dan.vodnar@usamvcluj.ro (D.C.V.); \\ cristina.coman@usamvcluj.ro (C.C.); socaciucarmen@gmail.com (C.S.) \\ 2 Department of Environmental and Plant Protection, University of Agricultural Sciences and Veterinary \\ Medicine, Calea Mănăștur 3-5, 400372 Cluj-Napoca, Romania; francisc_dulf@yahoo.com \\ 3 Instituto Universitario de Ingeniería de Alimentos para el Desarrollo, Universidad Politécnica de Valencia, \\ Camino de Vera s/n, 46022 Valencia, Spain; marcasgi@hotmail.com (M.C.-G.); pedfisu@tal.upv.es (P.J.F.) \\ * Correspondence: ramona.suharoschi@usamvcluj.ro; Tel.: +40-730-630-252
}

Received: 5 September 2017; Accepted: 21 November 2017; Published: 24 November 2017

\begin{abstract}
Probiotics are bacteria that can provide health benefits to consumers and are suitable to be added to a variety of foods. In this research, viability of immobilized Lactobacillus casei in alginate with or without sea buckthorn lipid extract were studied during heat treatment and with an in vitro gastrointestinal model. The characterization of the lipid extract was also done using the UV-Vis spectrometry (UV-Vis), high-performance liquid chromatography photodiode array detection method (HPLC-PDA), gas chromatography coupled with mass spectrometry (GS-MS) and Cryo scanning electron microscopy (Cryo-SEM). During heat treatment, the entrapped probiotic cells proved high viability ( $>6 \mathrm{CFU} \log / \mathrm{g}$ ), even at temperatures above $50{ }^{\circ} \mathrm{C}$. The rich in monounsaturated fatty acids sea buckthorn fraction improved the in vitro digestion passage regarding the probiotic viability. The survival of the probiotic cells was 15\% higher after $2 \mathrm{~h}$ in the acidic medium of the simulated gastric fluid in the sample where L. casei was encapsulated with the sea buckthorn extract compared with the samples where no extract was added. Thus, this approach may be effective for the future development of probiotic-supplemented foods as foods with health welfare for the consumers.
\end{abstract}

Keywords: Lactobacillus casei; heat treatment; gastrointestinal passage; sea buckthorn; encapsulation

\section{Introduction}

Lately, consumer interest in probiotic ingestion has increased as well as the preoccupation of cell viability at eating time. The most known and utilized products containing probiotics are mainly fermented dairy foods [1].

Probiotics are defined as live microorganisms which confer a beneficial health effect to the host when ingested in adequate amounts [2]. Species such as Lactobacillus, Bifidobacteria and Saccharomyces are the most utilized probiotic strains [3]. Lactobacillus casei, for example, was shown to improve or prevent diseases such as intestinal disorders [3,4], urogenital infections [5], obesity [6], cardiovascular diseases [7], and dental and liver diseases [8-10], and to generally support the immune system [11].

Many papers debate the effect of different prebiotics (food for probiotic cells) on the microflora but the association of probiotic cells with other functional elements is still quite limited. 
Sea buckthorn popularity has increased due to its potential as a functional food and nutraceutical $[12,13]$. The lipid fraction of sea buckthorn represents a potential source monounsaturated fatty acids and carotenoids, mainly $\beta$-carotene, and can be used as food additive.

Carotenoids have an important photochemical and physiological role in flora, fauna and microorganisms [14]. In humans, carotenoids are considered to be responsible for the prevention of cardiovascular diseases, age-related degeneration and carcino-genesis due to the antioxidative function [15]. This antioxidative function is the one that protects microorganisms, in our case probiotics, from unfavorable environment conditions [16]. To our knowledge, this is the first research that associates and investigates the probiotic cell viability in the presence of a lipid fraction.

The effectiveness of probiotics intake, with all the claimed health benefits, requires ingestion of a sufficient amount of colony forming units (CFU) [17]. However, most ingested probiotic cells do not survive when passing through the gastric juice and decrease in number during storage or unfriendly environmental conditions [18,19]. A highly efficient method to alleviate these problems is cell encapsulation [20-22]. This versatile technology has been utilized in various fields with remarkable results.

Therefore, the present study aims to evaluate the influence of a lipid fraction of sea buckthorn on the viability of the free and immobilized Lactobacillus casei ATCC 393 during heat treatment and in vitro gastrointestinal model. The characterization of the lipid extract was also done using UV-Vis spectrometry, HPLC-PDA, GS-MS and Cryo-SEM. To our knowledge, this is the first study that associates and investigates the probiotic viability in the presence of a lipid fraction of sea buckthorn extract.

\section{Results}

\subsection{Sea Buckthorn Lipid Fraction: Characterization}

\subsubsection{HPLC-PDA and UV-VIS Spectroscopy Analysis}

The $\beta$-carotene was expressed as an area percent resulted from the HPLC-PDA chromatogram. According to the calibration curve made using $\beta$-carotene standard, the total content of $\beta$-carotene from the lipid fraction of sea buckthorn is $11 \%$ (approximately $5 \mathrm{mg} / 100 \mathrm{~g}$ ) from the total content of carotenoids. The total content of carotenoids determined using the absorbance value at $450 \mathrm{~nm}$ from the UV-VIS spectra was $44.7 \mathrm{mg} / 100 \mathrm{~g}$. The chromatogram revealed, next to $\beta$-carotene, other free carotenoids, such as lutein, zeaxanthin, $\beta$-cryptoxanthin, $\alpha$-carotene, and $\gamma$-carotene.

\subsubsection{GS-MS Analysis of FAMES}

Tables 1 and 2 show the identified fatty acids from the sea buckthorn lipid fraction as free and extracted from the monodisperse capsules fractions. GC-MS chromatograms revealed 19 fatty acids, including saturated fatty acids (SFA), monounsaturated fatty acids (MUFAs) and polyunsaturated fatty acids (PUFAs). The unpaired $t$-test showed that the percentage of fatty acids in the two forms of the sea buckthorn was not statistically different, proving a high encapsulation yield. Major fatty acids found in the lipid fraction of sea buckthorn are oleic (C18:1n-9), palmitoleic (C16:1n-7) (monounsaturated) and palmitic (C16:0) (saturated) acids. The fatty acids composition (Table 2) showed: MUFAs $>$ PUFAs, MUFAs $>$ SFAs. Furthermore, the analyzed lipid fraction was characterized by low level of PUFAs/SFAs and a good level of n-6/n-3 PUFAs, as a result of the dominants $(>61 \%)$ of MUFAs. The recommended essential fatty acid balance (n-6/n-3 PUFAs) reported in literature is between $1: 1$ and 4:1 $[23,24]$. 
Table 1. Fatty acid compositions (molar \% of total fatty acids) (determined by GS-MS) of total lipids from the lipid fraction of sea buckthorn (free and encapsulated).

\begin{tabular}{ccccc}
\hline Fatty Acids & \multicolumn{2}{c}{ SE Lipid Fraction } & \multicolumn{2}{c}{ SE from Capsules } \\
\hline & $\%$ & SD & \% & SD \\
\hline Caprylic & 0.04 & 0.01 & 0.01 & 0.01 \\
Capric & 0.03 & 0.01 & 0.02 & 0.01 \\
Lauric & 0.04 & 0.01 & 0.05 & 0.01 \\
Myristic & 0.18 & 0.02 & 0.20 & 0.02 \\
Z-11-Tetradecenoic acid & 0.05 & 0.01 & 0.02 & 0.01 \\
Pentadecanoic & 0.07 & 0.02 & 0.06 & 0.01 \\
Palmitic & 26.59 & 1.33 & 27.94 & 1.45 \\
7-Hexadecenoic acid & 0.03 & 0.01 & 0.03 & 0.01 \\
Palmitoleic & 26.2 & 1.31 & 25.15 & 1.30 \\
Margaric acid & 0.02 & 0.01 & 0.04 & 0.01 \\
Stearic & 1.11 & 0.06 & 1.13 & 0.06 \\
Oleic & 27.73 & 1.40 & 27.83 & 1.35 \\
Vaccenic & 10.73 & 0.55 & 10.05 & 0.45 \\
Linoleic & 5.42 & 0.25 & 5.73 & 0.29 \\
Alfa-linolenic & 1.45 & 0.07 & 1.36 & 0.07 \\
Arachidic & 0.14 & 0.02 & 0.14 & 0.01 \\
Gondoic & 0.11 & 0.02 & 0.16 & 0.02 \\
Behenic & 0.02 & 0.01 & 0.03 & 0.01 \\
Erucic & 0.03 & 0.01 & 0.08 & 0.01 \\
\hline
\end{tabular}

The values represent the mean of tree samples, analyzed in triplicate. SD, standard deviation.

Table 2. The composition (molar \% of total fatty acids) classed in total lipids from the lipid fraction of sea buckthorn (free and encapsulated).

\begin{tabular}{ccc}
\hline Fatty Acids & SE lipid Fraction & SE from Capsules \\
\hline$\Sigma$ SFAs & $28.25 \pm 1.41^{\mathrm{b}} \mathrm{a}^{\mathrm{a}}$ & $29.62 \pm 1.48^{\mathrm{b}} \mathrm{a}$ \\
$\Sigma$ MUFAs & $64.88 \pm 3.24^{\mathrm{a}}{ }_{\mathrm{a}}$ & $63.29 \pm 3.16^{\mathrm{a}}{ }_{\mathrm{a}}$ \\
$\Sigma$ PUFAs & $6.87 \pm 0.34^{\mathrm{c}} \mathrm{a}^{\mathrm{a}}$ & $7.09 \pm 0.35^{\mathrm{c}} \mathrm{a}^{\mathrm{a}}$ \\
n-3 PUFA & $1.45 \pm 0.07 \mathrm{a}_{\mathrm{a}}$ & $1.36 \pm 0.07 \mathrm{a}$ \\
n-6 PUFA & $5.42 \pm 0.27 \mathrm{a}$ & $5.73 \pm 0.29 \mathrm{a}$ \\
n-6/n-3 & $3.74 \mathrm{a}_{\mathrm{a}}$ & $4.21 \mathrm{a}$ \\
PUFAs/SFAs & $0.24 \mathrm{a}$ & $0.24 \mathrm{a}$ \\
\hline
\end{tabular}

Values represent mean \pm SD of three samples analyzed individually in triplicate $(n=3 \times 3)$. The means in the same column followed by different superscript letters $(a, b, c)$ indicate significant differences $(p<0.05)$ among fatty acid classes (ANOVA "Tukey's Multiple Comparison Test"). The means in the same row followed by different subscript letters indicate no significant differences $(p<0.05)$ among lipid classes of samples (unpaired $t$-test); SFAs, saturated fatty acids; MUFAs, monounsaturated fatty acids; PUFAs, polyunsaturated fatty acids.

\subsubsection{Low-Temperature Scanning Electron Microscopy (Cryo-SEM)}

In Figure 1, it is possible to observe that the sea buckthorn presents barriers for oil extraction by mechanical extraction techniques. In Figure 1a, the epidermal tissue is observed, and Figure 1b shows the same tissue in more detail. In both figures, it is observed that the cover of the sea buckthorn has a high cell compaction. In the epidermal tissue and in the tissue immediately below (hypodermis), the presence of fat globules is not observed. The accumulation of fat globules appears in the parenchymatic tissue, which is formed by polygonal cells [25] (Figure 1c,d). In both figures, a high concentration of fat globules within the cell is shown. In Figure 1c, two fat globules, $36 \mu \mathrm{m}$ and $15 \mu \mathrm{m}$ in diameter, are highlighted. In Figure 1d, a fat globule of $20 \mu \mathrm{m}$ in diameter is observed. Finally, in Figure 1e,f, lipidic globules of $15 \mu \mathrm{m}$ and $8 \mu \mathrm{m}$ in diameter, respectively, are shown in detail. The analysis of the parenchymatic tissue shows lipid globules of different sizes, being on average between 6 and $45 \mu \mathrm{m}$ in diameter. The high accumulation of fat globules in the parenchymatic tissue, 
away from the epidermal tissue, denotes that the mechanical extraction is the most suitable method for obtaining the lipid phase of the medium.

a)

b)
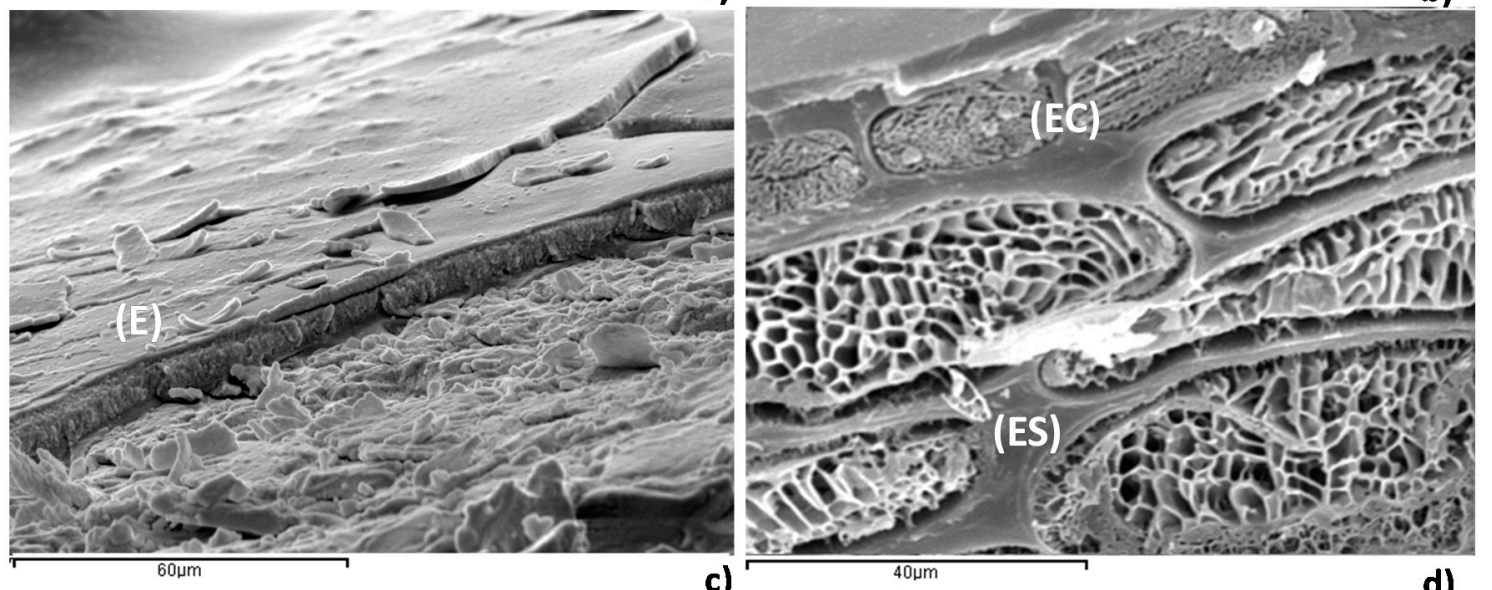

c)
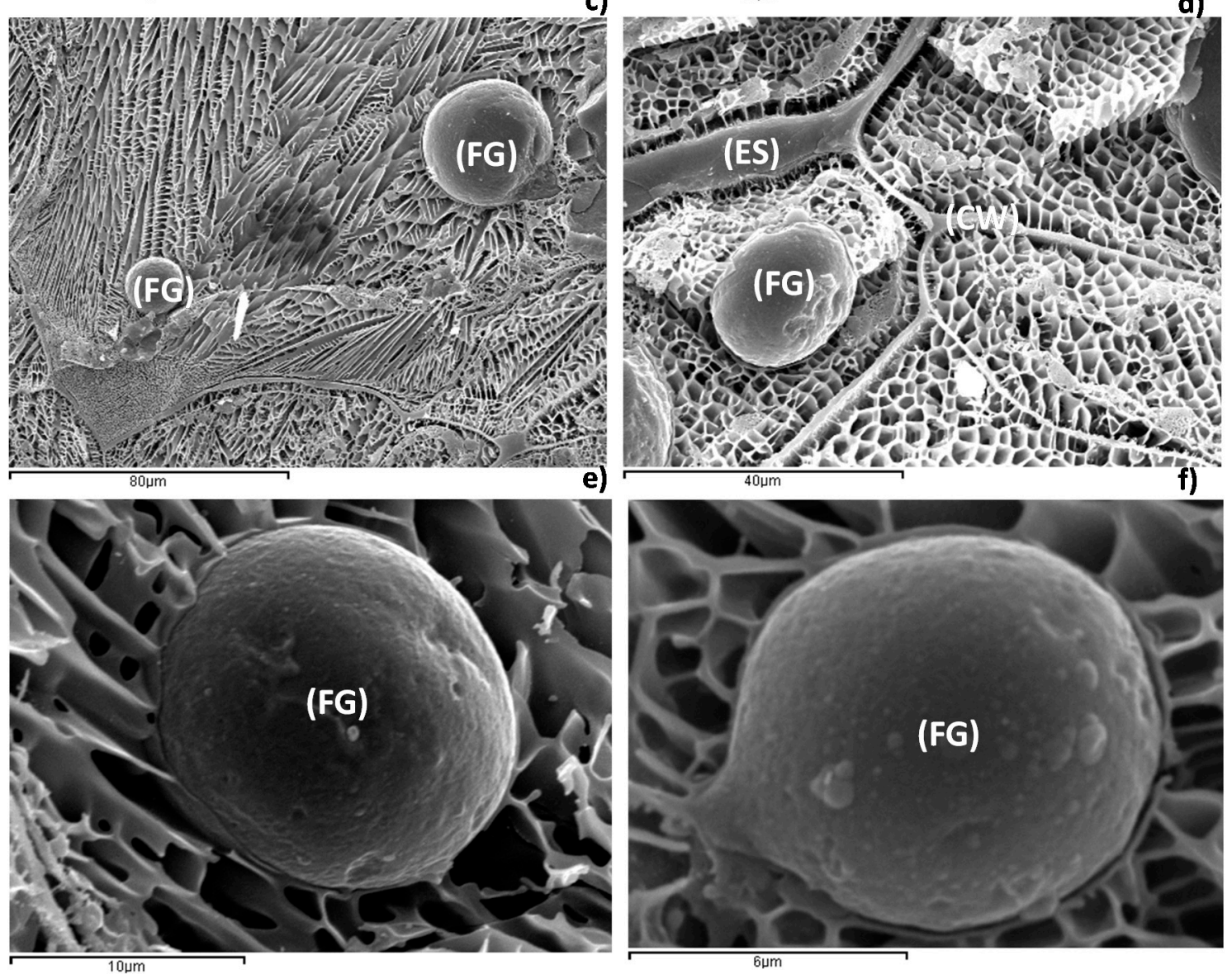

Figure 1. Micrographies of fresh sea buckthorn: (a) epidermic tissue at $1000 \times$; (b) epidermic tissue at $1500 \times$; (c) parenchymatic tissue at $750 \times$; (d) parenchymatic tissue at $1500 \times$; (e) fat globules detail at 5000×; and (f) fat globules detail at 10,000×. E, Epidermic tissue; EC, Epidermic cells; ES, Extracellular space; FG, Fat globules; and CW, Cell wall. 


\subsection{Probiotic Cell Encapsulation}

In this study, the probiotic-containing capsules production registered an average production of $9.48 \mathrm{~g} / \mathrm{min}$ material. In the case of the capsules containing the sea buckthorn lipid fraction, the production was not significantly influenced in terms of quantity $(9.51 \mathrm{~g} / \mathrm{min})$.

\subsection{Capsules Characterization. Entrapment Efficiency}

Table 3 shows size results for the two types of capsules and encapsulation yields. The yield entrapment in sodium alginate based capsules can be influenced by the capsule size, the hardening time in calcium chloride, the concentration of cells and the solution concentration [26,27]. It was observed, according to the calculated sphericity factor (SF), that the capsules with sea buckthorn had a nicer, rounder shape (SF $=0.01 \pm 0.02$, value is mean $(n=3) \pm$ standard deviation) than the ones without sea buckthorn ( $\mathrm{SF}=0.05 \pm 0.01$, value is mean $(n=3) \pm$ standard deviation).

Table 3. Size and encapsulation yield.

\begin{tabular}{ccc}
\hline Microparticles & Microparticles Size $(\boldsymbol{\mu m})(\boldsymbol{n = 1 0 )}$ & Encapsulation Yield $(\boldsymbol{\%})(\boldsymbol{n}=\mathbf{1 0})$ \\
\hline Alginate $1.5 \%$ & $1255.5 \pm 12.7$ & $96.13 \pm 0.28^{\mathrm{a}}$ \\
Alginate $1.5 \%$ and $10 \%$ SE & $1285.5 \pm 1.3$ & $98.46 \pm 1.08^{\mathrm{b}}$ \\
\hline
\end{tabular}

The means \pm SD with different letters $(\mathrm{a}, \mathrm{b})$ in the same column are significantly different $(n=3, p<0.05)$. $\mathrm{SE}$, sea buckthorn lipid fraction; $n$, number of measured capsules.

\subsection{Influence of Heat Treatment on the Probiotic Cells Viability}

Our experiments involved the determination of the heat resistance of the probiotic L. casei in the yogurt medium, with respect to the presence of sea buckthorn lipid fraction and encapsulation. As can be observed in Table 4, the temperature of the yogurt changed depending on the microwave power and the treatment time. The temperature means showed no significant differences between the samples with free and encapsulated L. casei, under the same treatment. As expected, the highest temperatures were observed for the sample treated $120 \mathrm{~s}$ at $850 \mathrm{~W}\left(\sim 65^{\circ} \mathrm{C}\right)$.

After an analyzing the data presented in Table 4, it can be stated that highest CFU log/g is in the sample YLSE (encapsulated with sea buckthorn lipid fraction) heated at $40{ }^{\circ} \mathrm{C}$.

Viable counts in the samples were reduced with about $25 \mathrm{CFU} \log / \mathrm{g}$ when the temperature reached $55^{\circ} \mathrm{C}$, compared with the highest CFU log/g count. All the viability measurements were expressed in CFU log/g. A trend that express a protective effect of encapsulation with sea buckthorn lipid extract was observed in the sample when heated at approximately $65{ }^{\circ} \mathrm{C}$ (Table 4 ). For the sample where sea buckthorn was used, the no-encapsulated sample counts were $26 \%$ lower than the encapsulated ones, at the highest temperature. Meanwhile, the decrease of viability in the samples where free and encapsulated L. casei were tested at the highest temperature was $23 \%$ lower. These facts show that encapsulation is a technique that efficiently protects the probiotic cells, maximizing its effect when used in combination with sea buckthorn lipid fraction addition. 
Table 4. Temperature variation in $250 \mathrm{~mL}$ yogurt in correlation with the time and the microwave frequency. Temperature unit is ${ }^{\circ} \mathrm{C}$. Viability of probiotic cells YLE, yogurt with encapsulated L. casei; YLS, yogurt with added L. casei and 10\% sea buckthorn lipid fraction; and YLSE, yogurt with encapsulated L. casei and $10 \%$ sea buckthorn lipid fraction after microwave treatment at: 100; 450; and $850 \mathrm{~W}$. Values represent mean \pm SD of three samples, analyzed individually in triplicate $(n=3 \times 3)$.

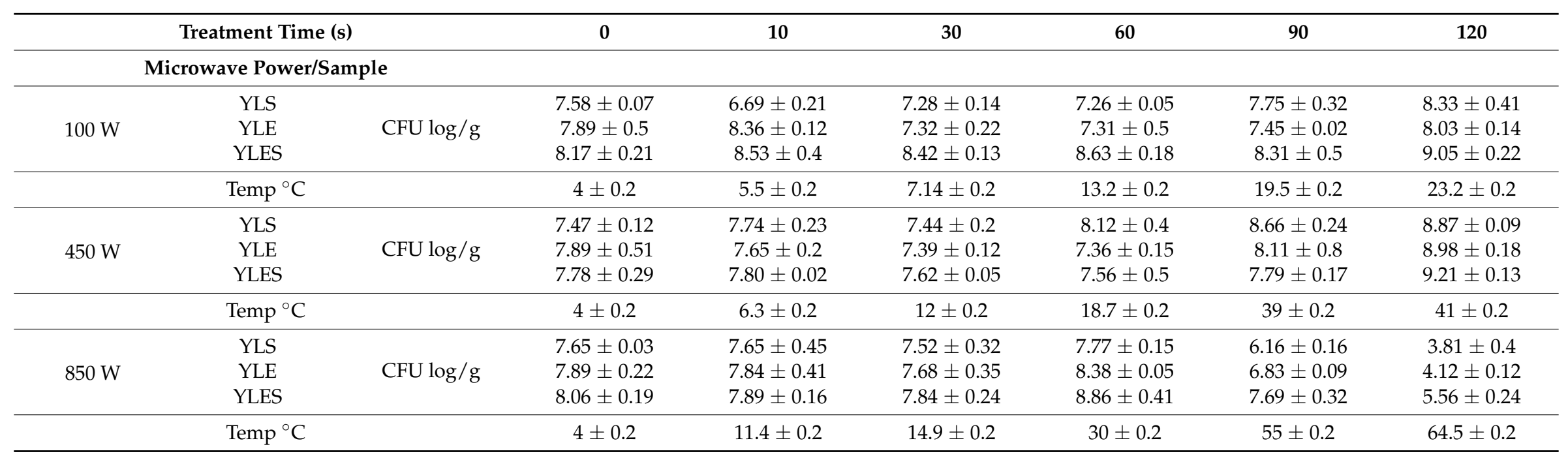




\subsection{In Vitro Gastrointestinal Model Assay}

For the in vitro digestion assay, two samples were used: probiotic loaded capsules with and without sea buckthorn extract (Figure 2). At the end of the assay, the viability of immobilized probiotic cells decreased by approximately $1.5 \mathrm{CFU} \log$ in the sample where no extract was used. Meanwhile, in the sample where sea buckthorn lipid extraction has been utilized, no loss of cell viability was observed. The simulated salivary fluid (SF) showed no influence regarding the viability of the probiotic cells: no significant changes were registered compared with the starting point. Viability of the probiotic cells was $15 \%$ higher after $2 \mathrm{~h}$ in the acidic media in the sample where L. casei was encapsulated with sea buckthorn extraction compared with the other sample. When a favorable $\mathrm{pH}$ was fulfilled, in the simulated intestinal fluid (SIF), the cells entrapped with the lipid fraction had the capacity to increase their number. Thus, the lipid extract did offer protection during in vitro gastrointestinal model and also sustained the growth of $L$. casei.

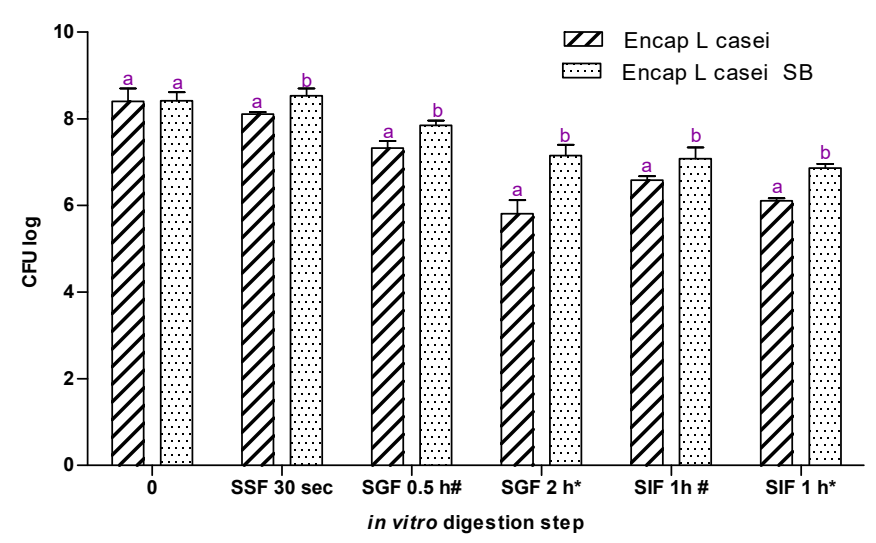

Figure 2. The viability of $L$. casei encapsulated with or without sea buckthorn lipid fraction, after the in vitro static digestion assay. SSF, simulated saliva fluid; SGF, simulated gastric fluid; SIF, simulated intestinal fluid; \#, the sample treated $0.5 \mathrm{~h}$ in SGF; *, the sample treated $2 \mathrm{~h}$ in SGF; a, b, different letters in the same group mean significant difference $(p<0.05, n=3 \times 3)$.

\section{Discussion}

In the present study, we have evaluated the influence of a lipid fraction of sea buckthorn on the viability of the free and alginate-encapsulated Lactobacillus casei ATCC 393 during the heat treatment and in vitro gastrointestinal model. Prior to utilization, the sea buckthorn lipid extract was characterized.

Several studies have reported that sea buckthorn is rich in carotenoids, which were shown to have prophylactic and therapeutic effects towards human's health, in particular, prevention of cardiovascular diseases and cancer $[28,29]$. Likewise, these bioactive molecules are applied to add value and improve the nutritional role and functionality of numerous foods; on this aspect, this study widens carotenoids effects with respect to probiotics. The resulted carotenoid content in the sea buckthorn lipid fraction utilized in this work was in agreement with other studies [30]. Lu et al. [31] described the carotenoids behavior at different temperature treatments to the formation of an aggregate. They link the increase of temperature from 15 to $\sim 50{ }^{\circ} \mathrm{C}$ to the increase of bioavailability of carotenoids due to the formation of J-aggregate (head-to-tail). This kind of aggregate can explain the rounder shape of the capsules when sea buckthorn lipid fraction is added. The trend that was reported before and discussed further by other works [32].

The composition of lipid fraction of the sea buckthorn is considered to further influence the probiotic viability. Recent studies [16,33] correlate the viability of the probiotics with new types of materials, such as sea buckthorn mucilage or omega-3 oil. Analyses and reports of the lipid fraction of the sea buckthorn are very scattered. The most analyzed ones are the fruits and derivate 
products (juice) $[30,34-36]$ or the seed oil $[12,13]$. Compared to lipid fraction of the seed, rich in essential fatty acids, such as linoleic acid $(\mathrm{C} 18: 2, \mathrm{n}-6)$ and $\alpha$-linoleic $(\mathrm{C} 18: 3, \mathrm{n}-3)$, the fruit lipid fraction contains high levels of saturated (palmitic (C16:0)), and monounsaturated (palmitoleic (C16:1n-7)) acids. The saturated fatty acids represent around $81 \%$ of the total fatty acids from this fraction. The lipid fraction is rich in palmitic acid and in monounsaturated fatty acids, namely palmitoleic (16:1) and oleic + vaccenic acids (18:1), which represented together around $91 \%$ of total fatty acids.

The lipid fraction of sea buckthorn represents a potential source of carotenoids, mainly $\beta$-carotene and fatty acids. It can be used as food additive, cosmetic ingredient, nutraceutical and, according to this study, as a protective source for L. casei. It is reported that for L. casei the metabolization of certain foods is more difficult than other strains [37]. Thus, further work can be conducted to understand better the protection mechanism of the sea buckthorn lipid fraction on different probiotic strains.

The presence of the sea buckthorn lipid fraction did not influence the capsules production concerning quantity. Instead, the shape and the size of the capsules were influenced, a trend also seen in other studies [38,39]. Large scale production of probiotic alginate capsules is quite scarce discussed in the literature. A production of approximately $9.51 \mathrm{~g}$ of capsules per minute, described in our study, is equivalent to little more than $0.5 \mathrm{~kg}$ per hour. That quantity can be utilized in almost 600 serving sizes of yogurt for example. The addition of the sea buckthorn to the alginate probiotic solution (slurry) made it creamier due to the extraction texture. This texture allows the utilization of lower concentration of alginate in the encapsulation solution, resulting in lower production costs. In our study, $1.5 \%$ alginate solution was used, but several other studies report higher concentrations [32,40,41].

It is well-known that the size of the formed capsules is influenced by the nozzle size, slurry viscosity and working parameters (frequency, flow rate) [27]. Our entrapment of probiotics in alginate matrix showed an encapsulation yield close to $100 \%$. Utilization of alginate for the encapsulation has valuable advantages, such as high encapsulation yield [40], resistance to stomach acidity [37], controlled release in the intestinal media for colonization and biocompatibility of the polymer [41]. For the samples where the sea buckthorn lipid fraction was utilized, a $2 \%$ higher yield was registered. Other studies reported that the presence of different additives, such as sea buckthorn mucilage, lucerne green juice, potato starch, etc. positively affected not only the viability of probiotics but also the encapsulation yield $[16,37,38,40]$.

The reduction in the CFU log pattern of the microwave treated probiotic cells was investigated using probiotic cell suspension or encapsulated probiotic cells in yogurt. The viable counts in the samples were found to diminish relative to an increase in a microwave heating temperature after a certain point (above $55^{\circ} \mathrm{C}$ ). For all samples, the temperature increased proportionally to the time of exposure to the microwave radiation and to the microwave power intensity, behavior reported by the Woo et al. [42]. According to our results, the addition of the lipid extract increased the viability of probiotic cells by almost $4 \%$. The survival of microorganisms during heat treatment is influenced by several factors. One of the main factors that vary from one Lactobacillus spp. to another is the potential of the strain to resist at high temperatures [43-46]. Gunenc et al. [16] reported an increase of $6 \%$ in the case where whole sea buckthorn was utilized with a Lactobacillus strain during storage over 14 days in comparison with the sample where no sea buckthorn was added. In our study, based on two-way ANOVA analysis, all viable and active counts in the samples where no encapsulation was used were significantly lower than the samples with encapsulated probiotics. We observed that the temperature was ensuring an activation of the viability of the started cultures with approximately $50 \%$ in the plain yogurt (with no added probiotic-Y) to a certain temperature $\left(40^{\circ} \mathrm{C}\right)$. In the samples with added L. casei, the temperature induced $8 \%$ (YL, yogurt with L. casei) and 18\% (YLS, yogurt with L. casei and sea buckthorn extract) increases in viability when the lipid extract was added. Temperatures above $50{ }^{\circ} \mathrm{C}$ caused a decrease of viable free probiotic cells. Comparing the encapsulated samples, the sample YLE (yogurt with encapsulated L. casei) registered approximately $50 \%$ loss in viability when it reached the highest temperature $\left(64.5^{\circ} \mathrm{C}\right)$. Meanwhile, the sample YLSE (yogurt with encapsulated L. casei and 
sea buckthorn extract) registered almost $10 \%$ higher loss, but the number of viable probiotics did not decrease below $5.5 \mathrm{CFU}$ log.

After the in vitro static digestion assay, we can conclude that the presence of sea buckthorn lipid extract positively influenced the viability of the probiotic cells. No significant difference could be observed after the treatment in the SSF (simulated salivary fluid), since the samples remain for only $30 \mathrm{~s}$ in this media with a neutral $\mathrm{pH}$. Most of the studies where the behavior of probiotics (free and encapsulated, with or without additives) is tested do not investigate the oral digestion phase. The short time of the food spends in the mouth may be the reason for this fact. Our results, which sustain that sea buckthorn lipid extract protects the entrapped probiotics in vitro gastrointestinal model assay, are in line with a study conducted by Gunenc et al. [16]. This study investigated the presence of whole fruits and purified mucilage of sea buckthorn and their influence on probiotic cell viability (L.acidophilus) during 28 days of storage at $4{ }^{\circ} \mathrm{C}$ and simulated gastrointestinal passage. In all of the samples where the sea buckthorn source was added, a significantly higher number of probiotic cells were counted after 28 days. The aforementioned study does not discuss the change in taste of the yogurt, despite the fact that is considered to be an important decision factor regarding the consumption, especially for children [47]. This element taste determined the use of only encapsulated samples. Another study conducted by Darjani [48] has investigated the role of inulin on L. casei during exposure to simulated gastrointestinal conditions. This study emphasized the effectiveness of encapsulation and even more of the presence of a supplement adding, which improved the probiotic cell viability with approximately $0.5 \mathrm{CFU}$ log compared with the sample where adding was used. In our study, the influence of the lipid extract presence was more visible in the samples that were incubated $2 \mathrm{~h}$ in SGF. After the low $\mathrm{pH}$ treatment, in the samples where no extract was used, the lost in viability was approximately 0.5 CFU log higher than in the other sample. The results suggest that co-encapsulation of $L$. casei with a sea buckthorn lipid extract constitutes an alternative for maintaining the probiotic viability during heat treatment and in vitro static digestion assay, ensuring also valuable fatty acids and highly bioavailable carotenoids.

\section{Materials and Methods}

\subsection{Sea Buckthorn (Hippophae rhamnoides) Lipid Fraction: Obtaining and Characterization}

Lipid fraction from fresh sea buckthorn was obtained from smashed and centrifuged berries collected from Cluj, Romania, and stored at $4{ }^{\circ} \mathrm{C}$ before use. Different analyses were conducted on the sea buckthorn lipid fraction such as UV-VIS spectrometry, HPLC, and GC-MS. Moreover, the microstructure of fresh sea buckthorn was analyzed by Cryo-SEM.

\subsubsection{HPLC-PDA and UV-VIS Analysis}

Total carotenoids were extracted from the freshly obtained puree $(0.5 \mathrm{~g})$ using methanol:ethyl acetate:petroleum ether (1:1:1, v/v/v). The mixture was mixed for $1 \mathrm{~min}$, kept $15 \mathrm{~min}$ in an ultrasonic bath and centrifuged for $10 \mathrm{~min}$ at $2000 \mathrm{RPM}$. The supernatant was collected and the extraction procedure was repeated two more times. The total volume of the final extraction was $5.5 \mathrm{~mL}$.

The qualitative analysis of the carotenoids extract was conducted using an HPLC coupled PDA detector. The quantity of $\beta$-carotene was determined using a compound standard and a calibration curve. A Shimadzu HPLC-PDA chromatograph was used employing a LiChrosorb RP 18 column. For the analysis, two mobile phases were used: solvent A-acetonitrile:water 9:1, $v / v$ with $0.25 \%$ trimethylamine; and solvent B-ethyl acetate with $0.25 \%$ trimethylamine. The total content of $\beta$-carotene was determined using the HPLC analysis. Calibration curves for $\beta$-carotene were prepared at seven concentrations in the range $0-300 \mu \mathrm{g} / \mathrm{mL}$ by plotting the peak area recorded by DAD against the known concentration of the standard. The linear regression factor of the calibration curves was greater than 0.98 . The total carotenoids content was determined spectrophotometrically using a Jasco 
V 530 spectrophotometer with a double beam. The UV-Vis spectra were registered at $300-550 \mathrm{~nm}$. Carotenoids content was calculated using the absorption value at $450 \mathrm{~nm}$ according to the formula:

$$
\mathrm{X}=\mathrm{A} \times \mathrm{Y} \times 1000 \times \text { dilution } / 2500 \times 100
$$

where $\mathrm{X}$ is the weight of carotenoids in the sample $(\mathrm{mg})$; $\mathrm{A}$ is the absorbance $(\lambda$ max $=450 \mathrm{~nm})$; $\mathrm{Y}$ is the volume of the sample $(\mathrm{mL}) ; 2500$ is the molar absorption coefficient $\left(\mathrm{E}_{1 \%}\right)$ for carotenoids.

Data were processed by specific software (Shimadzu LC Solution and Spectra Manager for Windows 10/NT).

\subsubsection{GS-MS Analysis of FAMEs}

The FAMEs (fatty acid methyl esters) were prepared using acid catalyzed transesterification of the total lipid fractions [49].

The analysis of FAMEs was achieved by capillary gas chromatography, using a PerkinElmer Clarus 600T GC-MS (PerkinElmer, Inc., Shelton, CT, USA). The column of the GC was a Supelcowax 10 $(60 \mathrm{~m} \times 0.25 \mathrm{~mm}$ i.d., $0.25 \mu \mathrm{m}$ film thickness; Supelco Inc., Bellefonte, PA, USA) [49]. The working temperature of the oven was set at $140{ }^{\circ} \mathrm{C}$, then increased to $220^{\circ} \mathrm{C}$ at $7{ }^{\circ} \mathrm{C} / \mathrm{min}$, and kept for $23 \mathrm{~min}$ at $220^{\circ} \mathrm{C}$. The injection volume was $0.5 \mu \mathrm{L}$ (split ratio of 1:24) and the temperature of the injector was set at $210^{\circ} \mathrm{C}$. The used carrier gas was helium, with a constant flow rate of $0.8 \mathrm{~mL} / \mathrm{min}$. Mass spectra were recorded at $70 \mathrm{eV}$ and using a trap current of $100 \mu \mathrm{A}$ with a source temperature of $150^{\circ} \mathrm{C}$. The MS was scanned at $m / z$ 22-395 for all GC-MS experiments. The identification of fatty acids was accomplished by comparing their retention times with those of known standards and the resulting mass spectra to those in the database (NIST MS Search 2.0). The amount of each fatty acid was expressed as peak area percentage of total fatty acids.

\subsubsection{Low-Temperature Scanning Electron Microscopy (Cryo-SEM)}

The Cryo-SEM experiments were carried out using a Jeol JSM-5410 scanning electron microscope (Jeol, Tokyo, Japan) coupled to a CryoACryostage CT-1500C unit (Oxford Instruments, Witney, UK). The instrument was operated at $15 \mathrm{kV}$, at a working distance of $15 \mathrm{~mm}$ and a temperature below $-130^{\circ} \mathrm{C}$. For the measurements, the sample was immersed in liquid nitrogen $\left(-210^{\circ} \mathrm{C}\right)$ and further transferred to the Cryostage at $1 \mathrm{kPa}$ where the sample was cut. The sublimation (etching) took place at $-95^{\circ} \mathrm{C}$. The final point was determined by direct observation at $5 \mathrm{kV}$ acceleration voltage. Prior to measurements, the sample was coated with gold in a vacuum $(0.2 \mathrm{kPa}, 3 \mathrm{~min}$, ionization current $2 \mathrm{~mA})$.

\subsection{Bacterial Strains and Culture Conditions}

L. casei ATCC 393 (ATCC) was cultivated sequentially in 10, 50, 100 and $400 \mathrm{~mL}$ sterile de Man, Rogosa and Sharpe (MRS) broth (Merck, Darmstadt, Germany) overnight at $37^{\circ} \mathrm{C}$. The cells were harvested by centrifugation (Eppendorf Centrifuge 5804 R, Hamburg, Germany) at 1500 RPM, 10 min at $4{ }^{\circ} \mathrm{C}$ and washed twice with $9 \mathrm{~g} / \mathrm{L} \mathrm{NaCl}$.

\subsection{Probiotic Cells Encapsulation}

For the encapsulation of the probiotic cells, we used a laminar flow drip casting method as described in a previews work [27], but with slight modifications. For this, $15 \mathrm{~g} / \mathrm{L}$ sterile sodium alginate solution was mixed with centrifuged and washed probiotic cells and dripped using a vibrational unit (Multinozzle Biotech-EncapBioSistems Inc. encapsulator) into a sterile $20 \mathrm{~g} / \mathrm{L}$ calcium chloride solution, used as the hardening bath according to the experimental design. A $350 \mathrm{~mm}$ nozzle was used. The obtained capsules were used fresh in the further experimental work. After the encapsulation, we obtained different types of samples described in Table 5. 
Table 5. Experimental design for evaluation of sea buckthorn extract addition effect on probiotic cell viability in different microwave treatment of inoculated yogurt.

\begin{tabular}{ccc}
\hline Yogurt trials & SE$^{*}$ & Sample Coding \\
\hline Yogurt with L. casei and 10\% SE & $10 \%$ & YLS \\
Yogurt with L. casei encapsulated & - & YLE \\
Yogurt with L. casei and $10 \%$ SE encapsulated & $10 \%$ & YLSE \\
\hline
\end{tabular}

$\mathrm{SE}^{*}$ - sea buckthorn lipid fraction.

\subsection{Capsules Characterization, Entrapment Efficiency and Sphericity}

The theoretical and the corrected diameter of the capsules was determined using a method described previously [50]. The capsules shape was quantified using the SF, which is given by the following equation:

$$
\mathrm{SF}=\mathrm{d}_{\max }-\mathrm{d}_{\min } / \mathrm{d}_{\max }+\mathrm{d}_{\text {myin }}
$$

where $d_{\max }$ is the largest diameter and $d_{\min }$ is the smallest diameter perpendicular to $d_{\max }$.

For the determination of the $d_{\max }$ and $d_{\text {min }}$, ten capsules were used and the average was calculated. The $d_{\max }$ and $d_{\min }$ were obtained using an optical microscope fitted with a calibrated micrometer scale.

The entrapment efficiency was determined according to a method previously described [51,52]:

$$
\text { Entrapment efficiency }=(\mathrm{a} \times \mathrm{F} / \mathrm{b}) \times 100
$$

where $\mathrm{a}$ is $\mathrm{CFU} \log / \mathrm{g}$ in the capsules, $\mathrm{b}$ is CFU $\log / \mathrm{g}$ in the mixture before encapsulation and $\mathrm{F}$ is the sphere packing factor [53], which was considered to be 0.70 for all calculations. The obtained capsules were characterized regarding size, surface and sphericity using an optical microscope.

\subsection{Heat Treatment}

L. casei incorporated in yogurt in free and encapsulated forms was treated under microwave heating at $100 \mathrm{~W}, 450 \mathrm{~W}$ and $850 \mathrm{~W}$. The microwave treatment was carried out for all the samples during 10, 30, 60, 90 and $120 \mathrm{~s}$, respectively, at all of the aforementioned microwave power levels. After each microwave treatment, the temperature of the samples was measured. Next, the viability of the probiotic cells from each sample was determined. The results were used to evaluate the influence of the microwave on the free and encapsulated L. casei, with or without sea buckthorn (lipid fraction of the puree). Survival curves at mentioned microwave power levels and temperatures $\left(4-80^{\circ} \mathrm{C}\right)$ were obtained. The temperature of all samples was approximately $4{ }^{\circ} \mathrm{C}$ before the microwave treatment.

\subsection{In Vitro Gastrointestinal Model}

For the in vitro digestion assay, a standardized static method described by Minekus et al. [54], with slight modifications, was used. For the oral phase, we mixed $5 \mathrm{~g}$ of sample (yogurt with encapsulated probiotic with or without sea buckthorn) with $3.5 \mathrm{~mL}$ simulated saliva fluid (SSF) made of $1.13 \mathrm{~g} / \mathrm{L} \mathrm{KCl}, 0.5 \mathrm{~g} / \mathrm{L} \mathrm{KH}_{2} \mathrm{PO}_{4}, 1.14 \mathrm{~g} / \mathrm{L} \mathrm{NaHCO}, 0.014 \mathrm{~g} / \mathrm{L} \mathrm{MgCl} 2 \cdot 6 \mathrm{H}_{2} \mathrm{O}$ and $0.006 \mathrm{~g} / \mathrm{L}\left(\mathrm{NH}_{4}\right)_{2} \mathrm{CO}_{3}$. After vigorous mixing, $0.5 \mathrm{~mL} \alpha$-amylase (Sigma, Darmstadt, Germany) solution $1500 \mathrm{U} / \mathrm{mL}, 25 \mu \mathrm{L}$ $0.3 \mathrm{M} \mathrm{CaCl}_{2}$ and $975 \mu \mathrm{L}$ water were added and mixed again. No mastication was mimicked, yogurt is a soft food, usually not chewed. The $\mathrm{pH}$ was adjusted with $1 \mathrm{M} \mathrm{NaOH}$ to a final $\mathrm{pH}$ of 7 .

After $30 \mathrm{~s}$ in the SSF, $10 \mathrm{~mL}$ of the oral liquid was moved in $7.5 \mathrm{~mL}$ simulated gastric fluid (SGF) stock solution made of $0.514 \mathrm{~g} / \mathrm{L} \mathrm{KCl}, 0.122 \mathrm{~g} / \mathrm{L} \mathrm{KH}_{2} \mathrm{PO}_{4}, 2.1 \mathrm{~g} / \mathrm{L} \mathrm{NaHCO}_{3}, 2.76 \mathrm{~g} / \mathrm{L} \mathrm{NaCl}$, $0.01 \mathrm{MgCl}_{2}\left(\mathrm{H}_{2} \mathrm{O}\right)_{6}$ and $0.048 \mathrm{~g} / \mathrm{L}\left(\mathrm{NH}_{4}\right)_{2} \mathrm{CO}_{3}$. To this digestion mixture, $1.6 \mathrm{~mL}$ porcine pepsin (Sigma, U.S.A) stock solution of 25,000 U/mL prepared in SGF, $5 \mu \mathrm{L} \mathrm{CaCl}_{3} 33.294 \mathrm{~g} / \mathrm{L}, 0.3 \mathrm{~mL} 1 \mathrm{M} \mathrm{HCl}$ to adjust the $\mathrm{pH}$ to 3 and $0.695 \mu \mathrm{L}$ water were added. 
After $0.5 \mathrm{~h}\left(^{*}\right)$ and $2 \mathrm{~h}(\#), 20 \mathrm{~mL}$ of the gastric chime was mixed with $11 \mathrm{~mL}$ of simulated intestinal fluid (SIF) made of $0.507 \mathrm{~g} / \mathrm{L} \mathrm{KCl}, 0.109 \mathrm{~g} / \mathrm{L} \mathrm{KH}_{2} \mathrm{PO}_{4}, 7.140 \mathrm{~g} / \mathrm{L} \mathrm{NaHCO} 3,2.244 \mathrm{~g} / \mathrm{L} \mathrm{NaCl}$, and $0.031 \mathrm{MgCl}_{2}\left(\mathrm{H}_{2} \mathrm{O}\right)_{6}$. To this mixture, $5 \mathrm{~mL}$ pancreatin solution $800 \mathrm{U} / \mathrm{mL}$ made in SIF, 2.5 bile salt solution $(65.371 \mathrm{~g} / \mathrm{L}), 40 \mu \mathrm{L} \mathrm{CaCl}_{2} 33.294 \mathrm{~g} / \mathrm{L}, 1.31 \mathrm{~mL}$ water and $0.14 \mathrm{~mL} 1 \mathrm{M} \mathrm{NaOH}$ were added to reach a $\mathrm{pH}$ of 7 .

\subsection{Probiotic Cells Viability Test}

For the determination of the probiotic cells viability, samples were diluted $(1: 9 w / v)$ in $9 \mathrm{~g} / \mathrm{L}$ sodium chloride solution. Aliquots of $100 \mu \mathrm{L}$ were spread on a Petri dish with MRS agar using a sterile Drigalski spatula. After $36 \mathrm{~h}$ of incubation at $37^{\circ} \mathrm{C}$, the colonies were counted. For the samples with microencapsulated probiotics, the capsules were beforehand treated in sodium phosphate buffer ( $\mathrm{pH}$ 6.5) for the release of entrapped probiotic cells.

\subsection{Statistical Analysis}

All the experiments were conducted in triplicates. The statistical evaluation was carried out using Graph Prism Version 4.0 (Graph Pad Software Inc., San Diego, CA, USA). Statistical differences among samples were estimated using Student's $t$-test and one-way analysis of variance (ANOVA). The significance of difference was defined at the $5 \%$ level $(p<0.05)$. Calculations regarding the capsules size determination were performed using Microsoft Excel 2010.

\section{Conclusions}

In conclusion, the presence of a lipid extraction of sea buckthorn can positively influence the viability of probiotic cells during heat treatment and in vitro gastrointestinal passage. The viability of probiotic cells can be improved by approximately $12 \%$ in yogurt if only consumed between 20 and $40^{\circ} \mathrm{C}$, and by about $16 \%$ if a lipid fraction of sea buckthorn is used in the encapsulated form of the probiotics. The rich in monounsaturated fatty acids sea buckthorn fraction improved the in vitro digestion passage of alginate encapsulated L. casei. The survival of the probiotic cells was $15 \%$ higher after $2 \mathrm{~h}$ in the acidic media of the simulated gastric fluid in the sample where L. casei was encapsulated with the sea buckthorn extract compared with the samples where no extract was added.

Acknowledgments: This work was supported by a grant of the Romanian National Authority for Scientific Research and Innovation, CNCS-UEFISCDI, project number PN-II-RU-TE-2014-4-1255 and PN-III-P2-2.1-CI-2017-0056.

Author Contributions: Oana Lelia Pop designed the studies, performed the experiments, analyzed data and wrote the paper; Francisc Vasile Dulf, Lucian Cuibus, Marta Castro-Giráldez and Pedro J. Fito performed the experiments; Dan Cristian Vodnar, Cristina Coman and Carmen Socaciu contributed reagents/materials/analysis tools and discussed the results; and Ramona Suharoschi designed the studies, analyzed data, discussed the results and wrote the paper.

Conflicts of Interest: The authors declare no conflict of interest.

\section{References}

1. Coghetto, C.C.; Flores, S.H.; Brinques, G.B.; Záchia Ayub, M.A. Viability and alternative uses of a dried powder, microencapsulated lactobacillus plantarum without the use of cold chain or dairy products. LWT Food Sci. Technol. 2016, 71, 54-59. [CrossRef]

2. Sardes, M.E. Probiotics: Definition, sources, selection, and uses. Clin. Infect. Dis. 2008, 1, S58-S61. [CrossRef]

3. Butel, M.J. Probiotics, gut microbiota and health. Médecine et Maladies Infectieuses 2014, 44, 1-8. [CrossRef] [PubMed]

4. $\quad$ Eckburg, P.; Bik, E.M.; Bernstein, C.; Purdom, E.; Dethlefsen, L.; Sargent, M.; Gill, S.; Nelson, K.; Relman, D. Diversity of the human intestinal microbial flora. Science 2005, 5728, 1635-1638. [CrossRef] [PubMed]

5. Marelli, G.; Papaleo, E.; FerrariI, A. Lactobacilli for prevention of urogenital infections: A review. Eur. Rev. Med. Farmacol. 2004, 8, 87-95. [CrossRef] 
6. Aguirre, M.; Venema, K. The art of targeting gut microbiota for tackling human obesity. Genes Nutr. 2015, 10, 1-12. [CrossRef] [PubMed]

7. Ivey, K.L.; Hodgson, J.M.; Kerr, D.A.; Thompson, P.L.; Stojceski, B.; Prince, R.L. The effect of yoghurt and its probiotics on blood pressure and serum lipid profile; a randomised controlled trial. Nutr. Metab. Cardiovasc. Dis. 2015, 25, 46-51. [CrossRef] [PubMed]

8. Chávez-Tapia, N.C.; González-Rodríguez, L.; Jeong, M.; López-Ramírez, Y.; Barbero-Becerra, V.; Juárez-Hernández, E.; Romero-Flores, J.L.; Arrese, M.; Méndez-Sánchez, N.; Uribe, M. Current evidence on the use of probiotics in liver diseases. J. Funct. Food 2015, 17, 137-151. [CrossRef]

9. Daliri, E.B.-M.; Lee, B.H. New perspectives on probiotics in health and disease. Food Sci. Hum. Wellness 2015, 4, 56-65. [CrossRef]

10. Vajro, P.; Poeta, M.; Pierri, L.; Pizza, C.; D'Aniello, R.; Sangermano, M.; Massa, G.; Paolella, G. Chapter 33-Probiotics to treat visceral obesity and related liver disease. In Nutrition in the Prevention and Treatment of Abdominal Obesity; Watson, R.R., Ed.; Academic Press: San Diego, CA, USA, 2014; pp. 363-380.

11. Amara, A.A.; Shibl, A. Role of probiotics in health improvement, infection control and disease treatment and management. Saudi Pharm. J. 2015, 23, 107-114. [CrossRef] [PubMed]

12. Tian, J.S.; Liu, C.C.; Xiang, H.; Zheng, X.F.; Peng, G.J.; Zhang, X.; Du, G.H.; Qin, X.M. Investigation on the antidepressant effect of sea buckthorn seed oil through the GC-MS-based metabolomics approach coupled with multivariate analysis. Food Funct. 2015, 6, 3585-3592. [CrossRef] [PubMed]

13. Zeb, A.; Ullah, S. Sea buckthorn seed oil protects against the oxidative stress produced by thermally oxidized lipids. Food Chem. 2015, 186, 6-12. [CrossRef] [PubMed]

14. Cao, H.; Wang, J.; Dong, X.; Han, Y.; Ma, Q.; Ding, Y.; Zhao, F.; Zhang, J.; Chen, H.; Xu, Q.; et al. Carotenoid accumulation affects redox status, starch metabolism, and flavonoid/anthocyanin accumulation in citrus. BMC Plant Biol. 2015, 15. [CrossRef] [PubMed]

15. Monego, D.L.; da Rosa, M.B.; do Nascimento, P.C. Applications of computational chemistry to the study of the antiradical activity of carotenoids: A review. Food Chem. 2017, 217, 37-44. [CrossRef] [PubMed]

16. Gunenc, A.; Khoury, C.; Legault, C.; Mirrashed, H.; Rijke, J.; Hosseinian, F. Seabuckthorn as a novel prebiotic source improves probiotic viability in yogurt. LWT Food Sci. Technol. 2016, 66, 490-495. [CrossRef]

17. Kumari, A.; Angmo, K.; Monika Bhalla, T.C. Probiotic attributes of indigenous Lactobacillus spp. Isolated from traditional fermented foods and beverages of north-western Himalayas using in vitro screening and principal component analysis. J. Food Sci. Technol. 2016, 53, 2463-2475. [CrossRef] [PubMed]

18. De Prisco, A.; Maresca, D.; Ongeng, D.; Mauriello, G. Microencapsulation by vibrating technology of the probiotic strain lactobacillus reuteri dsm 17938 to enhance its survival in foods and in gastrointestinal environment. LWT Food Sci. Technol. 2015, 61, 452-462. [CrossRef]

19. Ranadheera, C.S.; Evans, C.A.; Adams, M.C.; Baines, S.K. In vitro analysis of gastrointestinal tolerance and intestinal cell adhesion of probiotics in goat's milk ice cream and yogurt. Food. Res. Int. 2012, 49, 619-625. [CrossRef]

20. Belščak-Cvitanović, A.; Bušić, A.; Barišić, L.; Vrsaljko, D.; Karlović, S.; Špoljarić, I.; Vojvodić, A.; Mršić, G.; Komes, D. Emulsion templated microencapsulation of dandelion (Taraxacum officinale L.) polyphenols and $\beta$-carotene by ionotropic gelation of alginate and pectin. Food Hydrocoll. 2016, 57, 139-152. [CrossRef]

21. Coghetto, C.C.; Brinques, G.B.; Siqueira, N.M.; Pletsch, J.; Soares, R.M.D.; Ayub, M.A.Z. Electrospraying microencapsulation of lactobacillus plantarum enhances cell viability under refrigeration storage and simulated gastric and intestinal fluids. J. Funct. Food 2016, 24, 316-326. [CrossRef]

22. Farnworth, E.R.; Champagne, C.P. Production of Probiotic Cultures and Their Incorporation into Foods. In Probiotics, Prebiotics, and Synbiotics: Bioactive Foods in Health Promotion; Watson, R.R., Preedy, V., Eds.; Academic Press: San Diego, CA, USA, 2016; pp. 303-318.

23. Dulf, F.; Andrei, S.; Bunea, A.; Socaciu, C. Fatty acid and phytosterol contents of some romanian wild and cultivated berry pomaces. Chem. Pap. 2012, 66, 925-934. [CrossRef]

24. Simopoulos, A.P. The importance of the ratio of omega-6/omega-3 essential fatty acids. Biomed. Pharmacother. 2002, 56, 365-379. [CrossRef]

25. Ho, L.S.; Nair, A.; Yusof, H.M.; Kulaveerasingam, H.; Jangi, M.S. Morphometry of lipid bodies in embryo, kernel and mesocarp of oil palm: Its relationship to yield. Am. J. Plant Sci. 2014, 5, 1163-1173. [CrossRef] 
26. Chavarri, M.; Maranon, I.; Ares, R.; Ibanez, F.C.; Marzo, F.; Villaran, M.D.C. Microencapsulation of a probiotic and prebiotic in alginate-chitosan capsules improves survival in simulated gastro-intestinal conditions. Int. J. Food Microbiol. 2010, 142, 185-189. [CrossRef] [PubMed]

27. Pop, O.; Brandau, T.; Schwinn, J.; Vodnar, D.; Socaciu, C. The influence of different polymers on viability of bifidobacterium lactis $300 \mathrm{~b}$ during encapsulation, freeze-drying and storage. J. Food Sci. Technol. 2015, 52, 4146-4155. [CrossRef] [PubMed]

28. Mapelli-Brahm, P.; Corte-Real, J.; Meléndez-Martínez, A.J.; Bohn, T. Bioaccessibility of phytoene and phytofluene is superior to other carotenoids from selected fruit and vegetable juices. Food Chem. 2017, 229, 304-311. [CrossRef] [PubMed]

29. Martins, N.; Ferreira, I.C. Wastes and by-products: Upcoming sources of carotenoids for biotechnological purposes and health-related applications. Trends Food Sci. Technol. 2017, 62, 33-48. [CrossRef]

30. Pintea, A.; Varga, A.; Stepnowski, P.; Socaciu, C.; Culea, M.; Diehl, H.A. Chromatographic analysis of carotenol fatty acid esters in physalis alkekengi and hippophae rhamnoides. Phytochem. Anal. 2005, 16, 188-195. [CrossRef] [PubMed]

31. Lu, L.; Wu, J.; Wei, L.; Wu, F. Temperature dependence of aggregated structure of $\beta$-carotene by absorption spectral experiment and simulation. Spectrochim. Acta Part A Mol. Biomol. Spectrosc. 2016, 169, $116-121$. [CrossRef] [PubMed]

32. Durante, M.; Lenucci, M.S.; Laddomada, B.; Mita, G.; Caretto, S. Effects of sodium alginate bead encapsulation on the storage stability of durum wheat (Triticum durum Desf.) bran oil extracted by supercritical $\mathrm{CO}_{2}$. J. Agric. Food Chem. 2012, 60, 10689-10695. [CrossRef] [PubMed]

33. Eratte, D.; Wang, B.; Dowling, K.; Barrow, C.J.; Adhikari, B. Survival and fermentation activity of probiotic bacteria and oxidative stability of omega-3 oil in co-microcapsules during storage. J. Funct. Food 2016, 23, 485-496. [CrossRef]

34. Dulf, F.V. Fatty acids in berry lipids of six sea buckthorn (Hippophae rhamnoides L., subspecies Carpatica) cultivars grown in romania. Chem. Cent. J. 2012, 6. [CrossRef] [PubMed]

35. Wang, S.L.; Liu, L.P.; Jiao, L.X.; Fan, M.T. Volatile profile of sea buckthorn wines, raw juices and must in Qinghai (China). Int. J. Food Prop. 2011, 14, 776-785. [CrossRef]

36. Socaci, S.A.; Socaciu, C.; Tofană, M.; Raţi, I.V.; Pintea, A. In-tube extraction and gc-ms analysis of volatile components from wild and cultivated sea buckthorn (Hippophae rhamnoides L. ssp. Carpatica) berry varieties and juice. Phytochem. Anal. 2013, 24, 319-328. [CrossRef] [PubMed]

37. Peredo, A.G.; Beristain, C.I.; Pascual, L.A.; Azuara, E.; Jimenez, M. The effect of prebiotics on the viability of encapsulated probiotic bacteria. LWT Food Sci. Technol. 2016, 73, 191-196. [CrossRef]

38. Pop, O.L.; Vodnar, D.C.; Suharoschi, R.; Mudura, E.; Socaciu, C.L. Plantarumatcc 8014 entrapment with prebiotics and lucerne green juice and their behavior in simulated gastrointestinal conditions. J. Food Process Eng. 2015. [CrossRef]

39. Laos, K.; Lõugas, T.; Mändmets, A.; Vokk, R. Encapsulation of $\beta$-carotene from sea buckthorn (Hippophaë rhamnoides L.) juice in furcellaran beads. Innov. Food Sci. Emerg. 2007, 8, 395-398. [CrossRef]

40. Khosravi Zanjani, M.A.; Ghiassi Tarzi, B.; Sharifan, A.; Mohammadi, N. Microencapsulation of probiotics by calcium alginate-gelatinized starch with chitosan coating and evaluation of survival in simulated human gastro-intestinal condition. Iran. J. Pharm. Res. 2014, 13, 843-852. [PubMed]

41. Silva, D.; Pinto, L.F.V.; Bozukova, D.; Santos, L.F.; Serro, A.P.; Saramago, B. Chitosan/alginate based multilayers to control drug release from ophthalmic lens. Colloid Surf. B Biointerface 2016, 147, 81-89. [CrossRef] [PubMed]

42. Woo, I.S.; Rhee, I.K.; Park, H.D. Differential damage in bacterial cells by microwave radiation on the basis of cell wall structure. Appl. Environ. Microbiol. 2000, 66, 2243-2247. [CrossRef] [PubMed]

43. Haddaji, N.; Mahdhi, A.K.; Krifi, B.; Ismail, M.B.; Bakhrouf, A. Change in cell surface properties of lactobacillus casei under heat shock treatment. FEMS Microbiol. Lett. 2015, 362. [CrossRef] [PubMed]

44. Hsieh, F.C.; Lan, C.C.E.; Huang, T.Y.; Chen, K.W.; Chai, C.Y.; Chen, W.T.; Fang, A.H.; Chen, Y.H.; Wu, C.S. Heat-killed and live: Lactobacillus reuteri gmnl-263 exhibit similar effects on improving metabolic functions in high-fat diet-induced obese rats. Food Funct. 2016, 7, 2374-2388. [CrossRef] [PubMed]

45. Liévin-Le Moal, V. A gastrointestinal anti-infectious biotherapeutic agent: The heat-treated Lactobacillus LB. Therap. Adv. Gastroenterol. 2016, 9, 57-75. [CrossRef] [PubMed] 
46. Sidira, M.; Karapetsas, A.; Galanis, A.; Kanellaki, M.; Kourkoutas, Y. Effective survival of immobilized lactobacillus casei during ripening and heat treatment of probiotic dry-fermented sausages and investigation of the microbial dynamics. Meat Sci. 2014, 96, 948-955. [CrossRef] [PubMed]

47. Hartvig, D.; Hausner, H.; Wendin, K.; Bredie, W.L.P. Quinine sensitivity influences the acceptance of sea-buckthorn and grapefruit juices in 9- to 11-year-old children. Appetite 2014, 74, 70-78. [CrossRef] [PubMed]

48. Darjani, P.; Hosseini Nezhad, M.; Kadkhodaee, R.; Milani, E. Influence of prebiotic and coating materials on morphology and survival of a probiotic strain of lactobacillus casei exposed to simulated gastrointestinal conditions. LWT Food Sci. Technol. 2016, 73, 162-167. [CrossRef]

49. Dulf, F.V.; Vodnar, D.C.; Socaciu, C. Effects of solid-state fermentation with two filamentous fungi on the total phenolic contents, flavonoids, antioxidant activities and lipid fractions of plum fruit (Prunus domestica L.) by-products. Food Chem. 2016, 209, 27-36. [CrossRef] [PubMed]

50. Chan, E.-S.; Wong, S.-L.; Lee, P.-P.; Lee, J.-S.; Ti, T.B.; Zhang, Z.; Poncelet, D.; Ravindra, P.; Phan, S.-H.; Yim, Z.-H. Effects of starch filler on the physical properties of lyophilized calcium-alginate beads and the viability of encapsulated cells. Carbohydr. Polym. 2011, 83, 225-232. [CrossRef]

51. Sandoval-Castilla, O.; Lobato-Calleros, C.; Garcia-Galindo, H.S.; Alvarez-Ramirez, J.; Vernon-Carter, E.J. Textural properties of alginate-pectin beads and survivability of entrapped $\mathrm{lb}$. Casei in simulated gastrointestinal conditions and in yoghurt. Food Res. Int. 2010, 43, 111-117. [CrossRef]

52. Pop, O.L.; Brandau, T.; Vodnar, D.C.; Socaciu, C. Study of bifidobacterium lactic 300b survival during encapsulation, coating and freeze drying process and the release in alkaline media. Bull. Univ. Agric. Sci. Vet. 2012, 69, 372-379. [CrossRef]

53. Aste, T.; Weaire, D. The Pursuit of Perfect Packing, 2nd ed.; Taylor and Francis Group: Boca Raton, FL, USA, 2008.

54. Minekus, M.; Alminger, M.; Alvito, P.; Ballance, S.; Bohn, T.; Bourlieu, C.; Carriere, F.; Boutrou, R.; Corredig, M.; Dupont, D.; et al. A standardised static in vitro digestion method suitable for food-An international consensus. Food Funct. 2014, 5, 1113-1124. [CrossRef] [PubMed]

(C) 2017 by the authors. Licensee MDPI, Basel, Switzerland. This article is an open access article distributed under the terms and conditions of the Creative Commons Attribution (CC BY) license (http://creativecommons.org/licenses/by/4.0/). 